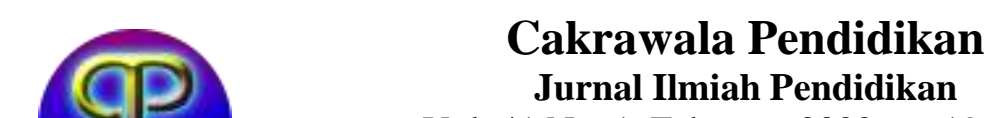

Vol. 41 No. 1, February 2022, pp.199-210

https://journal.uny.ac.id/index.php/cp/issue/view/2208

DOI: https://doi.org/10.21831/cp.v41i1.39651

\title{
Multiple intelligences mapping for tutors in Universitas Terbuka
}

\author{
Mery Berlian' ${ }^{1}$ Iqbal Miftakhul Mujtahid ${ }^{1}$, Rian Vebrianto ${ }^{2 *}$, Musa Thahir ${ }^{2}$ \\ ${ }^{1}$ Universitas Terbuka, ${ }^{2}$ Universitas Islam Negeri Sultan Syarif Kasim Riau \\ *Corresponding Author: rian.vebrianto@uin-suska.ac.id
}

\begin{abstract}
Tutors should be able to comprehend and build learning models that incorporate all multiple intelligences and incorporate integrated learning in order for all students' learning to be relevant and simple to comprehend. This study aims to determine: (1) a description of the profile and abilities of multiple intelligences of basic education tutors at UPBJJ UT Pekanbaru; and (2) differences in multiple intelligences based on gender, occupation, number of institutions, age, years of service, and ethnicity. This study uses a quantitative approach through a survey method, with a sample of 193 taken through a random sampling technique. All data were collected via online questionnaires and quantitatively analyzed using the IBM SPSS Statistics 23 application and the Two-Way Anova test. The results showed that: (1) the aspect of multiple intelligences, research subjects regularly have good multiple intelligences $(\mathrm{min}=6.7)$; (2) there is no difference in multiple intelligences based on gender, occupation, number of institutions, age, tenure, and ethnicity; and (3) there is a relationship between physical/kinesthetic, existential/spiritual, interpersonal, intrapersonal, logical/mathematical, musical/rhythmic, naturalistic, verbal/linguistic, and visual/spatial. The university's stakeholders will next provide relevant input and action to improve the tutors' resources and skills.
\end{abstract}

Keywords: multiple intelligences, mapping, tutor, Universitas Terbuka, $21^{\text {st }}$-century skills

\begin{tabular}{llll}
\hline Article history & & & \\
Received: & Revised: & Accepted: & Published: \\
18 October 2021 & 13 November 2021 & 20 January 2021 & 25 February 2022
\end{tabular}

Citation (APA Style): Berlian, M., Mujtahid, I. M., Vebrianto, R., \& Thahir, M. (2022). Multiple intelligences mapping for tutors in Universitas Terbuka. Cakrawala Pendidikan: Jurnal Ilmiah Pendidikan, 41(1), 154-165 https://doi.org/10.21831/cp.v41i1.39651

\section{INTRODUCTION}

Human resource quality enhancement is required in order for individuals to be productive and have a good work ethic. Education is one technique to increase the quality of human resources and their ability to meet job demands. Some jobs in Indonesia require that employees complete their education up to the college level. Some people, on the other hand, may not want to continue their education all the way to college. Economic issues, mindset, the environment, and the absence of transportation infrastructure as a means of attending lectures at preferred colleges are some of the factors affecting the community's low interest and motivation for education (Dela \& Kholilah, 2019). The ultimate aim of higher education is to produce educated people with good character, intelligence, and skills to transform Indonesia into a dignified and competitive nation with intact comprehensive competence, prosperity, security, welfare, and justice. According to Suryawati (2016), in order to fulfill its responsibilities in the twenty-first century, every educational institution must have a system in place to produce high-quality graduates in accordance with the higher education strategy.

In the reality, parts of multiple intelligences are devalued, and educators, particularly education stakeholders, pay less attention to them. One example is that education that has been implemented thus far has a tendency to prioritize implementation. Multiple Intelligences has a method for discovering skills, which refers to the process of discovering one's own abilities. This strategy assumes that everyone has a given level of intelligence, however, the majority of recent studies focus on students, including college and high school students (Kusniati, 2020). As a result, 
the focus of this study will be on mapping educators' multiple intelligences, particularly tutors', as regulators and facilitators in the learning process. The teacher's task is complex, given that they are dealing with the industrial revolution 4.0 and society 5.0, both of which require good understanding and application of multiple intelligences.

The MIT theory of intelligence asserts that everyone possesses some intelligence, and those different cognitive levels must be developed in order to approach learning. Every individual has at least eight intelligences, which must all be developed. Each of this eight intelligence has its own brain system, but when it comes to providing information, the eight types of intelligence that exist function together in a unique way. Each learner has a different proclivity towards each of the eight intelligences. Nonetheless, every technique found in each of the intelligences may be applied to all subjects in school, not just to the specific one (McClellan \& Conti, 2008). MIT has a number of distinguishing features that set it apart from other intelligence theories (Gardner, 1983): 1) MIT is a cognitive function theory; 2) individuals can master each of their intelligences to a respectable level, and 3) the intelligences integrate into complex ways.

The lack of attention from educators towards multiple intelligences is supported by the results of the research suggesting that one of the challenges students encounter in higher education is that the learning models they receive do not always fit their characteristics (Patimah et al., 2019). Educators are still having difficulty deciding on the best learning technique or paradigm (Sadiqin et al., 2017). There are no exceptions in this situation for prospective teachers, especially new students who are still adjusting to the higher education learning process. To address these issues, tutors should be able to create a learning model that incorporates all of the intelligence that students possess. Gardner emphasized that each individual possesses nine intelligences, which are linguistic, mathematical, spatial, musical, kinesthetic, interpersonal, intrapersonal, and naturalist intelligence (Gardner, 1998; Septiana \& Ikhsan, 2017; Syarifah, 2019). The multiple intelligences theory, according to Gardner, is based on valuing each individual's uniqueness, a diversity of learning techniques, a variety of models to measure them, and an almost endless number of ways to actualize themselves in this environment (Agustin, n.d.; Amir, 2013; H. Arifin, 2017). In the learning process, activities that need to be designed by educators are those that involve the development of multiple intelligences which integrate individual differences (Peluang Adilla et al., n.d.; Suniyah et al., 2018). Moreover, some students can demonstrate all of their intelligences, while others can only demonstrate one (Hoerr, 2007). The following elements must be present in learning strategies based on multiple intelligences: 1) they must be related to the syllabus; 2) they must employ a student-centered approach; 3) the strategies chosen must accommodate student learning styles; and 4) they must employ an authentic assessment rubric (Setiawati, 2019; Suniyah et al., 2018).

According to other studies, the use of multiple intelligence strategies in the classroom can help students learn more effectively if the types of learning instruments are available and teachers are trained in MI and the use of multiple intelligence strategies in the classroom can help students learn more effectively (Derakhshan \& Faribi, 2015).

The results of their research show that there is a significant relationship between intrapersonal intelligence and student GPA. This was strengthened by the $r$ count of 0.990 and the $\mathrm{r}$ table with $\mathrm{N}=200$ at the $5 \%$ significance level of 0.138 . As a result, $r$ count $>r$ table $(0.990$ $>0.138$ ), indicating a strong correlation. Furthermore, according to Hilyana and Khotimah's (2021) research, naturalistic intelligence received the highest percentage value of $38 \%$, music intelligence $24 \%$, visual-spatial intelligence $17 \%$, logical-mathematical intelligence and interpersonal intelligence $7 \%$, kinesthetic intelligence $4 \%$, intrapersonal intelligence $3 \%$, and linguistic intelligence $0 \%$.

With the above definition in mind, it's clear that the various intelligences that are constantly measured and researched are those of students and college students. Tutors' multiple intelligences, on the other hand, are rarely explored. Even so, the success of learning is dependent on the educators' teaching skills and abilities. The educator or tutor must first have good multiple intelligences in order to establish a student's multiple intelligences. LPTKs, such as Universitas Terbuka, are institutions that contribute to the quality of education. Universitas Terbuka is one of 
Indonesia's largest universities, with campuses spread across all provinces in Indonesia. Thus, researchers are interested in analyzing the level of multiple intelligences among tutors.

The novelty offered in this study is that researchers analyze differences in the multiple intelligences of tutors based on gender, occupation, number of institutions, age, years of service, and ethnicity. According to Masril et al. (2020), gender is one of the elements influencing differences in an individual's skills and creativity, hence it is necessary to do an analysis to see disparities in multiple intelligences based on gender. According to Muhammad (2018), Indonesia has a diverse ethnic population, resulting in a wide range of abilities. In a conclusion, it is vital to examine the data to see how ethnicity affects multiple intelligences.

The purpose of this study is to find out: (1) a description of the profile and abilities of basic education tutors at UPBJJ UT Pekanbaru; and (2) differences in multiple intelligences based on gender, occupation, number of institutions, age, years of service, and ethnicity. Therefore, tutors should be able to effectively deal with issues that arise as a result of adopting the MI-based strategy. A tutor must be able to manage a class and maintain positive interactions, communication, and connections with students.

\section{METHOD}

\section{Population and Sample}

This study uses a quantitative approach and employs a survey method. The researchers do not directly control the independent variable because the event has occurred (Creswell, 2014; Saunders, M., Lewis, PThornhill, 2016) The population in this study were UPBJJ UT Pekanbaru tutors who were spread throughout the province of Riau. Samples were taken using the random sampling technique, as it allows researchers to provide equal opportunities for each member of the population to be selected as a sample. The population in this study consisted of 352 elementary education tutors. The researchers then created a lottery to get the first sample. After getting the first sample, the chosen name is returned again so that the population remains intact and so that the probability of the next respondent remains the same as the first respondent. This step was repeated until the number of samples met the research needs of 193 tutors according to the Krejcie-Morgan Table (Krejcie \& Morgan, 1970).

\section{Procedures and Instruments}

A closed questionnaire was utilized to gather information. The Multiple Intelligences questionnaire was created using the theory that underpins the research variables (Creswell, 2014; Wiyono, 2018), as shown in Table 1. The instrument used was a nine-construct questionnaire with a scale of 9 in accordance with the theory of multiple intelligences (McClellan \& Conti, 2008). Valid and dependable instruments are required. To measure the instrument item validity level, researchers used the correlation product-moment formula to calculate the coefficient of validity based on the findings of the respondents' assessment of an item in terms of the extent to which it represents the construct being assessed. Table 1 shows the instrument validity results based on each variable's product-moment correlation coefficient.

\section{Table 1. Multiple intelligences instrument validity}

\begin{tabular}{clc}
\hline No & \multicolumn{1}{c}{ Constructs } & Product-moment correlation coefficient \\
\hline 1 & Physical/ Kinesthetic & 0.843 \\
2 & Existential/Spiritual & 0.887 \\
3 & Interpersonal & 0.856 \\
4 & Intrapersonal & 0.834 \\
5 & Logical thinking/ mathematics & 0.741 \\
6 & Musical/ rhythmic & 0.863 \\
7 & Naturalistic & 0.758 \\
8 & Verbal/ linguistic/ language & 0.807 \\
9 & Visual/ Spatial & 0.801 \\
\hline
\end{tabular}


Based on the correlation product-moment value, all items on the instrument were declared valid and feasible to be used in further research (Selaras et al., 2012). Then the reliability test was carried out using Cronbach's alpha with IBM SPSS Statistics 23 software. Table 2 presents the results of instrument reliability based on Cronbach's alpha.

Table 2. Multiple intelligences instrument reliability

\begin{tabular}{clc}
\hline No & \multicolumn{1}{c}{ Constructs } & Cronbach's alpha \\
\hline 1 & Physical/ Kinesthetic & 0.860 \\
2 & Existential/Spiritual & 0.869 \\
3 & Interpersonal & 0.863 \\
4 & Intrapersonal & 0.897 \\
5 & Logical thinking/ mathematics & 0.832 \\
6 & Musical/ rhythmic & 0.865 \\
7 & Naturalistic & 0.841 \\
8 & Verbal/ linguistic/ language & 0.853 \\
9 & Visual/ Spatial & 0.853 \\
\hline
\end{tabular}

The reliability values $(\alpha)$ for all of the constructs tested were greater than 0.60 in the current study. As a result, all of the constructs employed in this investigation were considered reliable. This meant that the instrument could measure what it was supposed to test and could be used to assess and evaluate the instrument of basic education tutors' multiple intelligences in Universitas Terbuka.

\section{Data Collection and Analysis Techniques}

Data were obtained via an online questionnaire with closed items that were evaluated between 1 and 5. A balanced 7-point Likert scale was used to assess the items. The Likert scale used in this study were (1) strongly disagree, (2) disagree, (3) moderately disagree, (4) neutral, (5) quite agree, (6) agree, (7) strongly agree. Quantitative data analysis was carried out using descriptive statistics and two-way ANOVA analysis. The mean and standard deviation were used in a descriptive statistical analysis using IBM SPSS Statistics 23 to describe the profile and abilities of basic education tutors at UPBJJ UT Pekanbaru.

\section{Table 3. Interpretation of multiple intelligences}

\begin{tabular}{cc}
\hline Averages & Criteria \\
\hline $1.00 \leq \min \leq 2.40$ & Not good \\
$2.41 \leq \min \leq 3.80$ & Moderate \\
$3.81 \leq \min \leq 5.00$ & Good \\
\hline
\end{tabular}

Furthermore, a two-way ANOVA analysis was used to determine differences in multiple intelligences based on gender, occupation, numbers of institutions, age, years of service, and ethnicity; and the relationship between physical/kinesthetic, existential/spiritual, interpersonal, intrapersonal, logical/mathematical thinking, musical/rhythmic, naturalistic, verbal/linguistic, and visual/spatial intelligences. The data analysis results were then interpreted as shown in Table 3.

\section{FINDING AND DISCUSSION}

\section{Finding}

\section{Research Subject Profile}

The research results in this study will be reported based on the planned research objectives and will be followed by a description of the research profile included in this study, with the following data: A total of 193 tutors from the UPBJJ Universitas Terbuka in Pekanbaru participated in this study. Table 4 shows a descriptive analysis of the research subject's profiles. 
Tabel 4. Research subject profiles

\begin{tabular}{|c|c|c|c|}
\hline Research profiles & Categories & $\mathrm{N}$ & Percentage (\%) \\
\hline \multirow[t]{2}{*}{ Gender } & Male & 101 & 52.3 \\
\hline & Female & 92 & 47.7 \\
\hline \multirow[t]{3}{*}{ Work base } & University & 67 & 34.7 \\
\hline & College & 12 & 6.2 \\
\hline & School & 114 & 59.1 \\
\hline Number of Institutions/ & One & 96 & 49.7 \\
\hline \multirow[t]{3}{*}{ Workplace } & Two & 70 & 36.3 \\
\hline & Three & 19 & 9.8 \\
\hline & More than three & 8 & 4.1 \\
\hline \multirow[t]{4}{*}{ Ethnicity } & Malay & 96 & 49.7 \\
\hline & Minang & 46 & 23.8 \\
\hline & Java & 32 & 16.6 \\
\hline & Batak & 7 & 3.6 \\
\hline \multirow[t]{4}{*}{ Age } & $<25$ years old & 1 & .5 \\
\hline & 25 s/d 33 years old & 39 & 20.2 \\
\hline & 33 s/d 40 years old & 41 & 21.2 \\
\hline & $>40$ years old & 112 & 58.0 \\
\hline \multirow[t]{4}{*}{ Length of service in UT } & $<1$ year & 21 & 10.9 \\
\hline & $1 \mathrm{~s} / \mathrm{d} 3$ years & 75 & 38.9 \\
\hline & $3 \mathrm{~s} / \mathrm{d} 5$ years & 32 & 16.6 \\
\hline & $>5$ years & 65 & 33.7 \\
\hline \multirow[t]{3}{*}{ Last education } & $\mathrm{S} 1$ & 14 & 7.3 \\
\hline & $\mathrm{S} 2$ & 168 & 87.0 \\
\hline & S3 & 11 & 5.7 \\
\hline
\end{tabular}

According to Table 4, there were 101 males (52.3\%) and 92 females (47.7\%), which is not very significant. The majority of the tutors, 114 people $(59.1 \%)$, came from work-based institutions. Furthermore, the average tutor who works for one job agency is 96 people $(49.7 \%)$. Meanwhile, $96.7 \%$ of tutors are Malays. The average age of basic education tutors is over 40, with a total of 112 people (58\%). With the age of tutors who are considered senior, it turns out that 140 tutors $(72.6 \%)$ have provided a sufficient service at Universitas Terbuka with an average length of service of 1 to 3 years and over 5 years. In addition, 168 tutors of basic education (87\%) have an average educational background at the Masters's degree. Based on the research profile data above, it showed that tutors of basic education have an ideal gender comparison and the potential to develop multiple intelligences.

\section{Descriptive Analysis}

The dependability of the instruments employed in this study was investigated, and the Cronbach alpha value was found to be 0.859 . It indicates that the correlation number is more than 0.60 (Z. Arifin, 2017; Joseph F. Hair, J., Black, W. C., Babin, B. J., \& Anderson, 2006). It signifies that the instruments used to test the tutors' multiple intelligences are adequate. As shown in Table 2 , high-quality instruments are critical for ensuring that the data collected is consistent and useful.

To fulfill the first purpose: (1) A description of the multiple intelligence profile and abilities of basic education tutors at UPBJJ UT Pekanbaru can be found in Table 5.

Table 5 shows that in the aspect of multiple intelligences, research subjects regularly have good multiple intelligences $(\min =6.7)$. From the above data, it can be seen that aspects of intrapersonal intelligence, interpersonal intelligence, and spiritual intelligence are the highest aspects in the mapping of tutors' multiple intelligences.

\section{Inferential Analysis}

Moreover, to fulfill the second purpose: (2) differences in multiple intelligences based on gender, occupation, number of institutions, age, years of service, and ethnicity of basic education tutors at UPBJJ UT Pekanbaru, the results of the tutors' inference perception on multiple intelligences are presented in Tables 6 to 8 . 
Table 5. Research subject perception of multiple intelligences

\begin{tabular}{llccc}
\hline No & \multicolumn{1}{c}{ Communication Construct } & $\mathrm{N}$ & $\mathrm{Min}$ & Category \\
\hline 1 & Physical Intelligence & 193 & 7,0 & Good \\
2 & Spiritual Intelligence & 193 & 7,1 & Good \\
3 & Interpersonal Intelligence & 193 & 7,1 & Good \\
4 & Intrapersonal Intelligence & 193 & 7,2 & Good \\
5 & logical thinking Intelligence & 193 & 6,7 & Good \\
6 & Musical Intelligence & 193 & 6,1 & Good \\
7 & Naturalistic Intelligence & 193 & 5,7 & Good \\
8 & Verbal Intelligence & 193 & 6,5 & Good \\
9 & Visual Intelligence & 193 & 6,6 & Good \\
Average Multiple Intelligences & 193 & 6,7 & Good \\
\hline
\end{tabular}

Table 6. Results of two-way anova analysis of multiple intelligence levels based on gender and work base

\begin{tabular}{llllll}
\hline \multicolumn{1}{c}{ Source } & $\begin{array}{l}\text { Type III Sum of } \\
\text { Squares }\end{array}$ & df & Mean Square & F & Sig. \\
\hline Corrected Model & $15.111^{\mathrm{a}}$ & 5 & 3.022 & 1.101 & .361 \\
Intercept & 3784.527 & 1 & 3784.527 & 1378.673 & .000 \\
Gender & .169 & 1 & .169 & .062 & .804 \\
Work base & 1.411 & 2 & .705 & .257 & .774 \\
Gender * Work Base & 7.310 & 2 & 3.655 & 1.332 & .267 \\
Error & 513.324 & 187 & 2.745 & & \\
Total & 9124.000 & 193 & & & \\
Corrected Total & 528.435 & 192 & &
\end{tabular}

Table 7. Results of two-way anova analysis of multiple intelligence levels based on gender and number of institutions

\begin{tabular}{llllll}
\hline \multicolumn{1}{c}{ Source } & $\begin{array}{l}\text { Type III Sum of } \\
\text { Squares }\end{array}$ & df & Mean Square & F & Sig. \\
\hline Corrected Model & $16.111^{\mathrm{a}}$ & 7 & 2.302 & .831 & .563 \\
Intercept & 3076.007 & 1 & 3076.007 & 1110.744 & .000 \\
Gender & 1.470 & 1 & 1.470 & .531 & .467 \\
number of institutions & 8.188 & 3 & 2.729 & .986 & .401 \\
Gender * number of & 1.066 & 3 & .355 & .128 & .943 \\
institutions & & & & & \\
Error & 512.325 & 185 & 2.769 & \\
Total & 9124.000 & 193 & & \\
Corrected Total & 528.435 & 192 & & \\
\hline a. $R$ Squared $=.030$ (Adjusted $R$ Squared $=-.006)$ &
\end{tabular}

Table 8. Results of two-way anova analysis of multiple intelligence levels based on gender and age

\begin{tabular}{llrlll}
\hline Source & $\begin{array}{l}\text { Type III Sum of } \\
\text { Squares }\end{array}$ & df & Mean Square & F & Sig. \\
\hline Corrected Model & $19.193^{\mathrm{a}}$ & 5 & 3.839 & 1.410 & .223 \\
Intercept & 6841.643 & 1 & 6841.643 & 2512.335 & .000 \\
Gender & 12.472 & 1 & 12.472 & 4.580 & .304 \\
Age & 4.676 & 2 & 2.338 & .859 & .425 \\
Gender * Age & 8.873 & 2 & 4.436 & 1.629 & .199 \\
Error & 509.242 & 187 & 2.723 & & \\
Total & 9124.000 & 193 & & & \\
Corrected Total & 528.435 & 192 & &
\end{tabular}


Table 6 shows that the gender of multiple intelligences in the model has no significant effect due to the value of sig. $>0.05(0.804>0.05)$; the work base of multiple intelligence in the model has no significant effect due to the value of sig. $>0.05(0.774>0.05)$ in the free sample.

Table 7 shows that the two-way Anova test result for the free sample revealed that gender has no significant effect on multiple intelligences in the model due to sig. > $0.05(0.467>0.05)$; the number of institutions has no significant effect on multiple intelligence in the model due to the value of sig. $>0.05(0.401>0.05)$.

Table 8 shows that the gender on multiple intelligences in the model has no significant effect due to sig. $>0.05(0.304>0.05)$ and the age of multiple intelligences in the model has no significant effect according to the value of sig. $>0.05(0.425>0.05)$ in the two-way ANOVA test for the free sample.

\section{Discussion}

Based on the study results, the mapping analysis outcomes of tutors' multiple intelligences at Universitas Terbuka are characterized as good.

An average score of 7 with a good category is reached in the physical intelligence construct. This demonstrates that the components in the physical intelligence construct correspond to individual characteristics that demonstrate physical intelligence ability (Arifmiboy, 2016). "I believe that is why I exist," stated Rene Descartes, a French philosopher. According to Thomas Armstrong, Descartes meant to show that there is no distinction between body and mind with this sentence (Amstrong, 2002). Based on these findings, we can conclude that physical intelligence refers to either the ability to utilize one's body to communicate ideas and feelings, as actors, athletes, dancers, sculptors, and surgeons do, or the ability to manage and improve one's physical abilities.

The spiritual intelligence construct gave an average score of 7.1 in the good category. This category demonstrates that Universitas Terbuka tutors have a high level of spiritual intelligence, as seen by the high percentage of results in their categories. The findings support Basuki's (2015) claim that spiritual intelligence is one of the indicators of increased motivation in achieving goals. Similarly, Coles' research demonstrates that spirituality comes from a natural curiosity and fascination with the world that began at a young age (Vialle, 2007). He came to the conclusion that spirituality stresses children's humanity and the role of parents, as well as educators' responsibility to assist students' spiritual development (Coles, 1990). Therefore, we as Muslims should be able to manage and develop the potential that Allah bestowed upon us in order to become good Muslims.

The interpersonal intelligence construct yielded an average score of 7.1 in the good category. This demonstrates that the construct corresponds to individual characteristics that indicate interpersonal intelligence ability (Sahnan, 2019). Not only are tutors with this intelligence capable of readily forming close friendships with their students, but they also have a strong ability to lead, organize, handle friendship disagreements, win compassion from other tutors, and so on (Fauziah, 2014; Syarifah, 2019). Interpersonal intelligence, according to the preceding definition, is the ability to understand and be sensitive to others' emotions, motivation, characters, and temperament feelings, as well as sensitivity to their natural expressions, sounds, and cues.

The intrapersonal intelligence construct obtained an average score of 7.2 in the good category. This demonstrates that intrapersonal intelligence is linked to personal qualities that indicate interpersonal intelligence ability (Haryati, 2014). A person with a high level of intrapersonal intelligence understands their own strengths and weaknesses, as well as their own desires and concerns, and can behave appropriately based on this knowledge.

The average value for the logical reasoning intelligence construct is 6.7 with a good category. This demonstrates that logical reasoning intelligence is consistent with the qualities of people who possess it (Gardner, 1983). Conceptual thinking is a skill that tutors with this cognitive potential (Solikhin \& Mustakim, 2015). According to Paul Suparno, it is quite simple to develop categorizations and explanations in their thinking and functioning methods. Their reasoning is logical, and they can readily create a cause-and-effect pattern (Ibda, 2015). As a result, logical 
thinking intelligence includes numerical processing skills as well as logic and common sense skills.

The musical intelligence construct generated an average score of 6.1 in the good category. Musical intelligence, according to Gardner, is the ability to create, express, and enjoy many types of music and sound (Ulfa, 2017). As a result, tutors with high musical intelligence reflect it in their singing in class and in assignments involving music, and they find it easy to recall things and express ideas when they are associated with music.

The average score of 5.7 with the good category is reached in the naturalistic intelligence construct. This demonstrates that naturalistic intelligence is consistent with the personality traits of naturalistic intelligence tutors (Yasbiati et al., 2017). According to Howard Gardner, as quoted by Thomas Armstrong, naturalistic intelligence can develop not only in persons who are close to flora and fauna but also in people who are far away from them (Syarifah, 2019). Gardner intended to convey through this depiction that intelligence is not confined to what can be measured by a few narrow intelligence tests or to what can be seen in students' successes as measured by school exams or examinations (Maulidah \& Santoso, 2012).

In the verbal intelligence construct, an average value of 6.5 with good category is obtained. This reveals that verbal intelligence is linked to individual factors that indicate verbal intelligence ability (Sahnan, 2019). People with low linguistic intelligence can still learn and utilize language, according to Paul Suparno, but the results will be inferior to those with high linguistic intelligence (Rofiah, 2016). Gardner defines linguistic intelligence as the capacity to effectively utilize and process words both orally and in writing (H. Arifin, 2017). Gardner discovered that persons with brain injury may still understand words and sentences but have trouble putting them together into sentences except in the most basic form (Gardner, 1983). Thus, teachers with high language intelligence potential are often identified by their interest in engaging in language-related activities such as reading, writing essays, writing poetry, and so on.

An average score of 6.6 with a good category is attained in the visual intelligence construct. This demonstrates that visual intelligence is linked to individual characteristics that indicate ability in this area (Haryati, 2014). Gardner claimed, according to Syarifah, that visual intelligence consists of a number of unrelated abilities, including the ability to recognize examples of the same element, the ability to transform or regard transformation from one element to another, the ability to transform such imagery, the ability to produce graphics of spatial information, and so on (Syarifah, 2019). As a result, people with this intelligence are more likely to think in or with visuals, and to learn more easily through visual presentations such as films, photos, videos, and model and slide demonstrations.

Multiple intelligences are not an intelligence test that compares a tutor's mental age to their chronological age to determine their intelligence; rather, it is a survey of preferences and habits that are frequently, regularly, and always practiced in everyday life or that can be observed in the teaching and learning process. The survey's findings serve as a guide for determining student intelligence tendencies. This survey statement, on the other hand, is a standardized model that has been tried by various experts, including (Amstrong, 2009; Gardner, 1983; Linda, C., Campbell, B., \& Dickinson, 1996; McKenzie, 2005). As a result, this survey is more commonly referred to as a tool for determining student learning styles (learning style research). "Intelligence cannot be measured as an absolute number (IQ), such as measuring a person's weight, height, or blood pressure," (Amstrong, 2009; Baum, S., Viens, J., \& Slatin, 2005; Gardner, 1983; Hoerr, 2000; Lazear, 1992; Linda, C., Campbell, B., \& Dickinson, 1996). To put it another way, intelligence is highly contextual and dynamic. As a result, effective ability growth necessitates the optimal use of the brain's capacities via a unique blend of all intellect. "The human brain is the most complex piece of machinery in the universe," according to Blackmore (Rose, C., \& Nicholl, 2001). As a result, tutors must have a thorough understanding of the diversity and characteristics of students, and they must always adjust to these differences.

The This study included a correlation test between components in addition to the difference test. Physical construct has a magnitude of 0,000 ; spiritual construct has a magnitude of 0,000 ; physical construct has a magnitude of 0,000 ; intrapersonal construct has a magnitude of 0,000 ; logical thinking construct has a magnitude of 0,000 ; musical construct has a magnitude of 0,000 ; 
naturalistic construct has a magnitude of 0,000 ; language construct has a magnitude of 0,000 , and visual construct has a magnitude of 0,000 . The significance test for the correlation coefficient revealed that sig. 0.05 . As a result, the nine constructs used in this study can help teachers improve their multiple intelligences. This finding is consistent with the hypothesis that multiple intelligence is a sort of intelligence shared by numerous people (Aryani, 2015). The levels of intelligence are not employed one at a time, but rather in conjunction with one another (Selaras et al., 2012). A tutor must pay close attention to each of the intelligences that students possess in order to maximize their intellectual potential. Knowing a student's MI level has numerous advantages for universities, tutors, and the students themselves (Fatonah, n.d.). According to Chatib, the MI idea highlights the concept of uniqueness, which finds assets in every student (Mulyani et al., 2019). Sarwono said that several factors, including inherited characteristics, contextual factors, and maturity factors, influenced the MI level in students. This maturity factor is inversely related to someone's age (Mulyani et al., 2019). As a result, students who are able to examine themselves will be aware of and able to evaluate their abilities and intelligence.

\section{CONCLUSION}

From the perception of Universitas Terbuka tutors, it can be concluded that their multiple intelligences are at an excellent stage, with an average number of each category as follows: physical intelligence (7.0); intellectual intelligence (7.1); interpersonal intelligence (7.0); intrapersonal intelligence (7.2); logical thinking intelligence (6.7); musical intelligence (6.1); naturalistic intelligence (5.7); verbal intelligence (6.4); and visual intelligence (6.6). The results also showed that there were no significant differences in multiple intelligences based on gender, work base, number of institutions, age, length of service, and ethnicity. The results of the study also showed that there was a significant relationship between physical, spiritual, interpersonal, intrapersonal, logical thinking, music, naturalistic, verbal, and visual. Judging from the value of the correlation coefficient, kinesthetic intelligence and interpersonal intelligence have the highest value of 0.881 . In conclusion, the two constructs are better at increasing the multiple intelligences of tutors.

\section{REFERENCES}

Agustin, M. (n.d.). Mengenali dan mengembangkan potensi kecerdasan jamak anak sejak dini sebagai tonggak awal melahirkan generasi emas.

Amir, A. (2013). Pembelajaran matematika dengan menggunakan kecerdasan majemuk (multiple intelligences). Logaritma, $1(01), \quad 1-14 . \quad \mathrm{http} / / /$ jurnal.iainpadangsidimpuan.ac.id/index.php/LGR/article/download/196/177

Amstrong, T. (2002). 7 Kinds of smart: Menemukan dan meningkatkan kecerdasan berdasarkan teori multiple intelligences. Gramedia Pustaka Utama.

Amstrong, T. (2009). Multiple intelligences in the classroom 3 edition. ASCD.

Amstrong, T. (2014). Kecerdasan jamak dalam membaca dan menulis.

Arfiyanti, R., \& Nuryanti, M. (2016). Optimalisasi kecerdasan majemuk dalam pembelajaran literasi. FKIP Unswagati.

Arifin, H. (2017). Konsep multiple intelligences system pada sekolah menengah pertama al washliyah 8 medan dalam perspektif islam. Jurnal EduTech, 3(1), 52-73.

Arifin, Z. (2017). Kriteria instrumen dalam suatu penelitian. Jurnal Theorems (The Original Research of Mathematics), 2(1), 28-36.

Arifmiboy. (2016). Multiple intelligences: mengoptimalkan kecerdasan anak sebagai upaya dalam mempersiapkan generasi emas masa depan. International Seminar on Education 2016, 69-84. 
Aryani, A. D. (2015). Model pembelajaran berdasarkan teori multiple intellegence yang dominan dalam kelas pada materi tekanan. Edusains, 6(2). https://doi.org/10.15408/es.v6i2.1114

Basuki, K. H. (2015). Pengaruh kecerdasan spiritual dan motivasi belajar terhadap prestasi belajar matematika. Formatif: Jurnal Ilmiah Pendidikan MIPA, 5(2), 120-133. https://doi.org/10.30998/formatif.v5i2.332

Baum, S., Viens, J., \& Slatin, B. (2005). Multiple intelligences in the elementary classroom. Teacher College, Columbia University.

Bybee, R. W. (2013). The case for STEM education - challenges and opportunities. NSTA Press.

Coles, R. (1990). The spiritual life of children. Harper Collins.

Creswell, J. C. (2014). Research design: Qualitative, quantitative, and mixed methods approach (4th ed). SAGE Publications Inc.

Dela, V. L., \& Kholilah. (2019). Minat remaja melanjutkan pendidikan ke perguruan tinggi ditinjau dari kondisi ekonomi keluarga di desa manyabar kecamatan panyabungan. Jurnal Wahana Konseling, 2(2), 72-80.

Derakhshan, A., \& Faribi, M. (2015). Multiple intelligences: Language learning and teaching. International Journal of English Linguistics, 5(4), 63-72. https://doi.org/10.5539/ijel.v5n4p63

Fatonah, S. (n.d.). Menumbuhkan kecerdasan majemuk (multiple intelligence) anak dengan mengenal gaya belajarnya dalam pembelajaran IPA SD. 229-246.

Fauziah, N. (2014). Empati, persahabatan, dan kecerdasan adversitas pada mahasiswa yang sedang skripsi. Jurnal Psikologi Undip, 13(1), 78-92. https://doi.org/10.14710/jpu.13.1.78-92

Fikriyah, F. Z., \& Aziz, J. A. (2018). Penerapan konsep multiple intelligences pada pembelajaran PAI. IQ (Ilmu Al-Qur'an): Jurnal Pendidikan Islam, 1(02), 220-244. https://doi.org/10.37542/iq.v1i02.17

Gardner, H. (1983). Frames of mind: the theory of multiple intelligences. Basic Books.

Gardner, H. (1998). Multiple Intelligences: The Theory in Practice. BasicBooks.

Haryati, S. (2014). Pengembangan intelegensi majemuk dalam proses pembelajaran. Jurnal FKIP Untidar, 14(2), 114-124.

Hilyana, F. S., \& Khotimah, T. (2021). Analysis of student activities in e-learning based on multiple intelligences. Journal of Physics: Conference Series, 1,1779. https://doi.org/10.1088/1742-6596/1779/1/012054

Hoerr, T. R. (2000). Becoming a multiple intelligences school. ASCD.

Hoerr, T. R. (2007). Buku kerja multiple intelligences. Kaifa.

Ibda, F. (2015). Perkembangan kognitif: teori jean piaget. Intelektualita, 3(1), 242904.

Joseph F. Hair, J., Black, W. C., Babin, B. J., \& Anderson, R. E. (2006). Multivariate data analysis. Pearson Educational International.

Krejcie, R. V, \& Morgan, D. W. (1970). Determining sample size for research activities. Educational and Psychological Measurement, 30(3), 607-610. https://doi.org/10.1177/001316447003000308

Kusniati, E. (2020). Strategi pembelajaran berbasis multiple intelligences. Auladuna: Jurnal Prodi Pendidikan Guru Madrasah Ibtidaiyah, 2(2), 59-75. https://doi.org/10.36835/au.v2i2.416

Lazear, D. G. (1992). Teaching for multiple intelligences. Phi Delta Kappa Education Foundation. 
Linda, C., Campbell, B., \& Dickinson, D. (1996). Teaching and learning through multiple intelligences. MA. Allyn \& Bacon.

Masril, M., Dakhi, O., Nasution, T., \& Ambiyar, A. (2020). Analisis gender dan intellectual intelligence terhadap kreativitas. Edukasi: Jurnal Pendidikan, 18(2), 182. https://doi.org/10.31571/edukasi.v18i2.1847

Maulidah, N., \& Santoso, A. (2012). Permainan konstruktif untuk meningkatkan kemampuan multiple intelligence (visual-spasial dan interpersonal). Jurnal Bimbingan Dan Konseling Islam, 02(01), 27-47.

McClellan, J. A., \& Conti, G. J. (2008). Identify the multiple intelligences of your students. Journal of Adult Education, 37(1), 13-32. http://search.ebscohost.com/login.aspx?direct=true\&db=eric\&AN=EJ891071\&site=ehost -live

McKenzie, W. (2005). Multiple intelligences and instructional technology. International Society for Technology in Education.

Muhammad, J. (2018). Perkembangan kemampuan fisik (kelentukan, kekuatan otot ekstensor, dan kelincahan) orang dewasa muda ditinjau dari usia dan etnik. Journal Power of Sports, 1(2), 1. https://doi.org/10.25273/jpos.v1i2.2249

Mulyani, K., D, R., Selaras, G. H., \& Fitri, R. (2019). Multiple intelligences of students in SMPN 22 padang multiple intelligences peserta didik kelas IX SMPN 22 Padang. Atrium Pendidikan Biologi, 4(2), 112-119.

Patimah, S., Sholahuddin, A., \& Sadiqin, I. K. (2019). Studi kasus identifikasi gaya belajar dan multiple intelligences mahasiswa baru calon guru kimia. Quantum: Jurnal Inovasi Pendidikan Sains, 10(1), 76. https://doi.org/10.20527/quantum.v10i1.5945

Peluang Adilla, J., Zubainur, A., Adilla, S., \& Ahmad, A. (n.d.). Pembelajaran matematika yang berorientasi multiple intelligences pada persamaan dan pertidaksamaan linier satu variabel.

Rofiah, N. H. (2016). Menerapkan multiple intelligences dalam pembelajaran di sekolah dasar. Jurnal Dinamika Pendidikan Dasar, 8(1), 69-79. http://jurnalnasional.ump.ac.id/index.php/Dinamika/article/view/937/875

Rose, C., \& Nicholl, M. J. (2001). Accelerated learning for the 21 centuries (cara belajar cepat abad XXI). Penerjemahah: Dedi Ahimsa. Nuansa Kerjasama dengan Pusat Perbukuan Depdiknas.

Sadiqin, I. K., Santoso, U. T., \& Sholahuddin, A. (2017). Pemahaman konsep IPA siswa SMP melalui pembelajaran problem solving pada topik perubahan benda-benda di sekitar kita. Jurnal Inovasi Pendidikan IPA, 3(1), 52. https://doi.org/10.21831/jipi.v3i1.12554

Sahnan, A. (2019). Multiple intelligence dalam pembelajaran PAI (Al-Qur`An Hadits Sd/Mi). Auladuna: Jurnal Prodi Pendidikan Guru Madrasah Ibtidaiyah, 1(1), 44-66. https://doi.org/10.36835/au.v1i1.162

Saunders, M., Lewis, PThornhill, A. (2016). Research methods for business students(7th ed.). Pearson Education Limited.

Selaras, G. H., Anhar, A., \& Sumarmin, R. (2012). Hubungan multiple intelligences dengan hasil belajar biologi siswa kelas X SMAN di kota padang. 22-34.

Septiana, K. G., \& Ikhsan, J. (2017). Pengaruh penerapan multiple intelligences dengan model PBL terhadap pemahaman konsep dan kemampuan berpikir kreatif. Jurnal Edukasi Matematika dan Sains, 5(1), 43. https://doi.org/10.25273/jems.v5i1.1785 
Setiawati, L. (2019). Pembelajaran berbasis multiple intelligences. TERAMPIL: Jurnal Pendidikan dan Pembelajaran Dasar, 6(2), 140-150. https://doi.org/10.24042/terampil.v6i2.5180

Solikhin, \& Mustakim. (2015). Prestasi belajar dengan pembelajaran think pair share (TPS) berbantuan media. Jurnal Pendidikan, 16, 74-99.

Suniyah, S., Rohmadi, M., \& Sulistiyo, E. T. (2018). Implementasi strategi pembelajaran menulis berbasis multiple intelligences. Sekolah Dasar: Kajian Teori dan Praktik Pendidikan, 27(2), 174-182. https://doi.org/10.17977/um009v27i22018p174

Suryawati, E. (2016). Pengembangan model peningkatan kompetensi dan daya saing lulusan MIPA LPTK berbasis KKNI dan kerangka TPCK.

Syarifah, S. (2019). Konsep kecerdasan majemuk howard gardner. SUSTAINABLE: Jurnal Kajian Mutu Pendidikan, 2(2), 176-197. https://doi.org/10.32923/kjmp.v2i2.987

Ulfa. (2017). Pengembangan kecerdasan musikal dalam pembelajaran musik angklung pada anak usia 5-6 tahun di TK seling jurnal program studi pgra optimalisasi pengembangan multiple intelligences pada anak usia dini di ra alrosyid kendal dander bojonegoro. 3, 76-93.

Vialle, W. J. (2007). Spiritual intelligence: an important dimension of giftedness. Values and Foundations in Gifted Education, 4(3), 171-186.

Wiyono, B. B. (2018). The effect of self-evaluation on the principals' transformational leadership, teachers' work motivation, teamwork effectiveness, and school improvement. International Journal of Leadership in Education, 21(6), 705-725. https://doi.org/10.1080/13603124.2017.1318960

Yasbiati, Y., Giyartini, R., \& Lutfiana, A. (2017). Upaya meningkatkan kecerdasan naturalis melalui kegiatan bercocok tanam di Bambim Al-Abror kecamatan Mangkubumi kota Tasikmalaya. Jurnal Paud Agapedia, 1(2), 203-213. https://doi.org/10.17509/jpa.v1i2.9360 